\title{
Brouwer and Nietzsche: views about life, views about logic
}

\author{
Miriam Franchella - Dipartimento di Filosofia - Università degli Studi \\ Via Festa del Perdono 7 - Milano - Italy \\ e-mail: miriam.franchella@unimi.it
}

\begin{abstract}
Both Nietzsche and Brouwer were unconventional people that dared to challenge the traditional views about logic: both maintained that Aristotelian logic wasn't either absolute or intrinsic to man. They draw such opinion from their general views about life as a struggle to power, where logic was a weapon. A detailed analysis and a comparison of their contributions to philosophy of logic is still missing. Here I intend to present the results of my research on this subject, by taking into account also the contributions by Steinhart, Schutte and Hales.
\end{abstract}

Key words: intuitionism, philosophy of logic, epistemology.

\section{Introduction}

Both Nietzsche and Brouwer had a stark personality that had no problem with presenting unconventional opinions. In particular, they dared to challenge the traditional view that considered Aristotelian logic as something absolute and intrinsic to man. Each of them developed this opinion in a different way but they both grounded it on a view of life that considered it as a struggle for power, where logic was a weapon. So, it is interesting to analyse in detail their starting points, the core of their opinion about logic and their consequences. In this paper I intend to present these aspects that have been little investigated ${ }^{1}$, in particular for what concerns a comparison between the authors. Since we are in a framework of history of logic, more acquaintance with Brouwer than with Nietzsche is supposed. Therefore, I will introduce each aspect of my comparison starting with Brouwer, although he lived after Nietzsche ${ }^{2}$.

\section{Life}

1.1. Brouwer had a very gloomy and pessimistic view of life that he described in detail in his 1905 pamphlet "Life, art and mysticism": life is suffering, only suffering, due to the desire and the will to power, which leads to the search for new targets, fatigue loads and concerns.

It is part of the balance of the eternal and omnipresent life that everyone is called away from this earthly existence when one's time has come. Until then man suffers in mind and body as befits his evil mood of thrift, his lust for power, his vanity and fear. (LAM, p. 392)

\footnotetext{
${ }^{1}$ Vladimir Tasić in his Mathematics and the roots of post-modernist thought designed a short comparison between Brouwer and Nietzsche, by aiming to show the partial similarities between the mathematical and the postmodern philosophical thought in the $20^{\text {th }}$ century, even if he stated (p. 47) that Brouwer seems closer to early Romanticism than to Nietzsche as far as Brouwer claimed the impossibility of being sure of an unambigous transmission of messages through words, resembling Humboldt's view that no one means the same thing as someone else. Tasić however noticed that Brouwer and Nietzsche "share a penchant for being shocking", by stressing that both of them refer to the "will" and both of them consider the so-called "real world" as an apparition; still, only for Brouwer there can be space in mathematics for creativity. (Tasić 2001, pp. 46-47) We will reconsider Tasić's opinions at the end of this paper.

${ }^{2}$ We have no direct reference to Nietzsche by Brouwer. Only in a letter from Adama van Scheltema to Brouwer (06.08.1097), his friend described himself as "Apollonius" and him as "Dionysus" according to the terminology present in Nietzsche's "The birth of tragedy". Brouwer replied (18.08.1907) that he would read the book. (Brouwer-Scheltema 1984) But after then the subject was not been reconsidered in a letter by him.
} 
Therefore, it is a source of frustrations and disappointments:

Life of the individual is an illusion, an anxious and laborious pursuit of ends- disillusionment. [...] Life of mankind as a whole is an arrogant tearing up and devouring its nest on this pure hearth, messing up its mothering growth, gnawing and mutilating her and making her rich creative power sterile, until all life has been swallowed up and the human cancer has withered on the barren planet. (LAM, pp. 392-3).

We can alleviate this suffering, returning to our 'self' and seeing the illusory bubble of space and time vanish: with it disappear also the negative emotions that it had produced:

If you however succeed in overcoming all inertia and proceed, you will find that passion will be silenced, you will feel dead to the old world of perception, of time and space, and all other forms of plurality; and your eyes, no longer blindfolded, will be opened to a scene of joyful quiescence (LAM, p.393) Your journey through this sad world will be a steady passage in a light and colorful cloud, full of love for all that is clear in it [...] for in your eyes it is no longer a reality separated from the self, but directed from within the self and with the self. You will no longer ask what to do: all will be clear of its own. (LAM, p. 394)

\subsection{Nietzsche was well conscious of the suffering aspects in human life:}

Wenn Jemand mit einem „seelischen Schmerz“ nicht fertig wird, so liegt das, grob geredet, nicht an seiner „Seele“; wahrscheinlicher noch an seinem Bauche (grob geredet, wie gesagt: womit noch keineswegs der Wunsch ausgedrückt ist, auch grob gehört, grob verstanden zu werden...) Ein starker und wohlgerathener Mensch verdaut seine Erlebnisse (Thaten, Unthaten eingerechnet) wie er seine Mahlzeiten verdaut, selbst wenn er harte Bissen zu verschlucken hat. (GM III, 16)

Schmerz ist auch eine Lust, Fluch ist auch ein Segen, Nacht ist auch eine Sonne, — geht davon oder ihr lernt: ein Weiser ist auch ein Narr. Sagtet ihr jemals Ja zu Einer Lust? Oh, meine Freunde, so sagtet ihr Ja auch zu allem Wehe. Alle Dinge sind verkettet, verfädelt, verliebt (Z IV, 10)

Still, he had, declaimed, advertised a joyful and positive conception of life: he entwined all his works around this theme, to enhance and defend life in its disruptive nature, in its originality, in creativity, from those who wanted to reduce it to mere survival, scheme, rule, requirement.

In media vita. - Nein! Das Leben hat mich nicht enttäuscht! Von Jahr zu Jahr finde ich es vielmehr wahrer, begehrenswerther und geheimnissvoller, - von jenem Tage an, wo der grosse Befreier über mich kam, jener Gedanke, dass das Leben ein Experiment des Erkennenden sein dürfe - und nicht eine Pflicht, nicht ein Verhängniss, nicht eine Betrügerei! (GS 324)

Life, for him, is animated by the will to power, as it will be according to Brouwer ${ }^{3}$. Nevertheless, Brouwer will consider this fact a negative attitude and will label as morally negative every contact

\footnotetext{
${ }^{3}$ The will to power had been a central theme in Schopenhauer's work, therefore it can be interesting to sketch here a comparison between our two authors and Schopenhauer. Nietzsche appreciated Schopenhauer at the very beginning of his production for his reference to the will to power and for the role that he attributed to the arts. Still, Nietzsche changed his mind definitively for the negative value that Schopenhauer attached to the will to power and for the "solutions" that he had proposed to contrast such will: some form of compassion and ascetism. Brouwer did not mention Schopenhauer in the papers where he described his Weltanschauung (except for a reference to his theory of colors as "polar splitting by the human eye" LAM, p. 413), but we can see some resemblance between he and Schopenhauer: they heir from Kant the idea that time, space and causality are aprioris (although Brouwer did not keep apriority of space any longer from 1907 on); they believed that the will to power is the motor of our life and is the cause of our suffering (but Brouwer considered such will as something individual not something unique - not as the noumenon behind all phenomena); they considered ascetism as a way out to the will to power (still, Brouwer did not consider that compassion could also be a solution). We could also add that the three authors shared misogyny (that prevented A. Heyting from inserting an integral version of LAM in Brouwer's Collected works - see CW I, p. 565). For what concerns a comparison between Brouwer and Schopenhauer see also Koetsier 2005.
} 
with the outside world. On the contrary, Nietzsche saw man as an explosion of will to power, i.e. a will to expansion, which must be accepted and encouraged:

Das Leben selbst gilt mir als Instinkt für Wachsthum, für Dauer, für Häufung von Kräften, für Macht: wo der Wille zur Macht fehlt, giebt es Niedergang. (A VI)

Within this framework he observed science, mathematics and physics.

\section{Science}

2.1. As for science, in 1905 Brouwer placed its origin in the intellect which makes a separation between a 'subject' and the world of 'objects' - provoking in this way desires and expectations:

Intellect has made him forfeit the amazing independence and directness of his rambling images by connecting them with each other rather than with the self. In this way the intellect made him persist with apparent security in the conviction of a 'reality'. (LAM p. 395)

Bodily awareness has strayed so far away that it is all concentrated in the human head, ignoring and excluding the rest of the body. At the same time man becomes convinced of his own existence as an individual and that of a separate and independent world of perception (LAM p.396)

After that, intellect connects experiences in a cause-effect relationship:

[...] In this life of lust and desire the intellect renders man the devilish service of linking two images of the imagination as means and end. Once in the grip of desire for one thing he is made to strive after another as a means to that end. (LAM 395)

The need for science is due to the abandonment of the self (that knows all about past and future, that knows what to do and where to go): without it, man grew more and more anxious about the future and began to crave for the power to predict its course. Therefore science came into being. At the beginning it aimed at concrete purposes and

it may happen that a direction is pursued which not only deviates into other dimensions but opposes the direction of the original end and therefore counteracts it. (LAM 395)

For instance, industry had originally worked in order to create in nature the most favorable conditions for human life, but, in manufacturing these products from nature's resources, it interfered with and upset the balance of nature itself and the human condition.

Later the means became an end in itself and science began to be practiced for its own sake; when it climbed too high it was almost completely shrouded in even greater isolation. The 'foundations' of its branches were investigated, and that soon became a new branch of science. 'As they climb higher and higher confusion grows until they are completely deranged'. (LAM 395)

Brouwer kept this negative viewpoint throughout his life but he refined it. Namely, in 1929 ('Mathematik, Wissenschaft und Sprache') he described man's causal attitude within 'mathematical obeservation'. Mathematical observation was as an act of our will finalised to our self-preservation, consisting of two phases: a temporal setting (zeitliche Einstellung) and a causal setting (kausale Einstellung):

Erstere ist nichts anderes als das intellektuelle Urphaenomenon der Auseinanderfallung eines Lebensmomentes in zwei qualitative verschiedene Dinge, von denen man das eine als dem anderen weichend und trotzdem als durch den Erinnerungsakt behauptet empfindet. Dabei wird gleichzeitig das gespaltene Lebensmoment vom Ich getrennt und nach einer als Anschauungswelt zu bezeichnenden Welt fuer sich verlegt. [...] Nunmehr besteht die kausale Einstellung im Willensakt der ,Identifizierung' verschiedener sich ueber Vergangenheit und Zukunft erstreckender zeitlicher 
Erscheinungsfolgen. Dabei entsteht ein als kausale Folge zu bezeichnendes gemeinsames Substrat dieser identifizierten Folgen. Als besonderer Fall der kausalen Einstellung tritt auf die gedankliche Bildung von Objekten, d.h. von beharrenden (einfachen oder zusammengesetzten) Dingen der Anschauungswelt, wodurch gleichzeitig die Anschauungswelt selbst stabilisiert wird. (CW I, p. 417)

'Mathematical observation' was followed by 'mathematical abstraction' (it points out the common substrat, from which the whole mathematics could be built) that made easier managing causal sequences when they were projected onto subsystems of mathematics.

In 1948 ('Consciousness, Philosophy, and Mathematics') he described the following steps from the inner self to the sciences:

Consciousness in its deepest home seems to oscillate slowly, will-lessly, and reversibly between stillness and sensation. And it seems that only the status of sensation allows the initial phenomenon of the said transition. The initial phenomenon is a move of time. By a move of time a present sensation gives way to another present sensation in such a way that consciousness retains the former one as a past sensation. [...] Through this distinction between present and past, [consciousness] recedes from both and from stillness, and becomes mind. As mind it takes the function of a subject experiencing the present as well as the past sensation as objet. [...] In measure of this estrangement, mind become disposed to desire and apprehension. [...] The free-will phenomenon of causal attention occurs. It performs identifications of different sensations ... and in this way creates iterative complexes of sensations. An iterative complex of sensations, whose elements have an unvariable order of succession in time, whilst if one of its elements occurs, all following elements are expected to occur likewise, in the right order of succession, is called a causal sequence. There are iterative complexes of sensations whose elements are permutable in point of time. Those which are completely extranged from the subject are called things and individuals. The whole of egoic sensations indissolubly connected with an individual is called soul.

Causal attention allows the development of the conative activity of the subject from spontaneous effort to forethinking enterprise by means of the free-will-phenomenon of cunning act. [...] mind, once having taken to causal attention, remains in a lasting causal tension [...] Systems of causal thinking underlying cooperative causal acts, are far more complicating than those inducing individual causal acts. Prominent among the former is scientific thinking, which is an economical and efficient way catalogues extensive groups of cooperative causal sequences. And this scientific thinking, in particular when concerned with technique, is based on mathematics. (CW I, pp. 481-482)

In other words, he introduced a distinction between simple consciousness and mind. Consciousness has perceptions in time; mind is a consciousness that separates itself as a subject against a 'world'. This separation causes desires. Therefore, a new way of seeing the world takes place: causal attention, i.e. the act of pointing out complexes of sensations. In this way, things, individuals and also causal sequences are shaped. The following step of mind is 'causal thinking', whose social and economical form is 'scientific thinking', which is based on mathematics.

Brouwer noticed that people, by seeing the similarities between own behavior and that of others', attached a mind also to them, but he warned against believing in a plurality of minds by showing how many contradictions such belief could generate:

Mind. By the choice of this term the subject in its scientific thinking is induced to place in each individual a mind with free-will dependence on this individual, thus elevating itself to a mind of a second order experiencing incognizable alien consciousness as sensations. Quod non est. [...] This moreover would have the consequence that the mind of second order would causally think about the plurified mind of first order... and so on. Usque ad infinitum. And this non sense would still go further. In the group of individuals $I_{1}, I_{2}, \ldots$ not only primary minds of first order $M_{1}, M_{2}, \ldots$ occur, but also mind of second order $\mathrm{M}_{\mathrm{kl}}$ (for every $\mathrm{k}$ and $\mathrm{l} \leq \mathrm{n}$ ) occurs, that is the sensations experienced by $\mathrm{I}_{\mathrm{k}}$ as a mind of second order from $I_{1}$. Likewise, besides the primary minds of second order $M_{k}$, mind $M_{r s t}$ occurs (for every $r, s$ and $t \leq n$ ), that is the sensation experienced by $I_{r}$ as a mind of third order from $M_{s t}$. And so on. Usque ad infinitum. Moreover, since the 
behavior from individual to individual differs only in degree and not in essence from the variation from individual to animal, so as a consequence of the plurality of mind, a mind would be assigned to animals as well ${ }^{4}$. (CW I p. 485)

This 'proof' of the impossibility of plurality of minds has as a consequence the impossibility of exchange of thought through languages. 'Thought are inseparabily bound up with subject'. (p. 485)

Still, language is an immediate companion of the intellect and aims to communicating. This is an external activity, a form of interaction, therefore, it involves a clash of wills.

For these reasons, language can never give a guarantee of success in its business and there is no way to check the result (except for the execution of trivial commands to be executed with concrete gestures visible), because the feedback would still take place using language. People start training themselves and their offspring in some crude sign language, painfully and with little success, for never has anyone been able to communicate with others, soul to soul. Language can only be the accompaniment of an already existing mutual understanding. Even when two people share the same needs and aspirations, they will be in constant danger of being led by their uncontrolled desires into different side roads and of drifting apart; they will suffer pain and anxiety in their struggle to keep together. (LAM p. 401) Only in very narrow domains of the imagination - as in the very abstract sciences that are completely separate from the world of perception and then skim the minimum of what is essentially human - only then mutual understanding can be maintained for some time:

Even in the case of the most restricted sciences, logic and mathematics - a sharp distinction between these two is hardly possible - no two different people will have the same conception of the fundamental concepts on which these two sciences are constructed, and yet their wills are parallel and in both there is a small, unimportant part of the brain which forces their attention in the same way. (LAM p. 401)

When people are fighting against a common enemy, then the language will serve its purpose: it will keep separate persons on the same path. But it is ridiculous the use of language when you try to express the subtle nuances of the will that are not part of the living reality of the people arguing: when, for example, so-called philosophers or metaphysicians argue among themselves of morality, God, consciousness, immortality, or of free will. These people do not even love each other, let alone share the same subtle movements of the soul; sometimes they even do not know each other personally. They either talk at cross-purposes or each builds his own little logical system which lacks any connection with reality. For logic is life in the human brain; it may accompany life outside the brain but it can never guide by virtue of its own power. (LAM p. 401) It is hard for the attention to break away from the intellect so much that only the most extraordinarily events make an impression and get through to the central human emotions. By means of language as the slave of an illusion of reality one cannot reveal the truth. (LAM p. 403)

Ridiculous is the use of language when there is an argument and people try to come to an agreement by means of reasoning. In this case, language, which presumes a harmony of will, may well be used to accompany strife and fighting. 'But they might just as well keep silent; they only play off their wills against each other and work on each other's desires and fears, and the strongest man wins.' (LAM p . 402)

Ridiculous is also the language of conversation, and comical is the language of conversation between boys and girls. 'In their case, there is already a harmony of will, and language is completely superfluous; indeed its only purpose is to hide this harmony of will.' (LAM p. 402) In everyday life language has only one sense as a means to hold together two people's wills already harmonious along the same path.

2.2 For Nietzsche, the intellect is the source from which metaphors spring out all the time. They are originally a wonderful product of human creativity. Still, intellect also aims to preserve the

\footnotetext{
${ }^{4}$ And this appeared absurd to Brouwer.
} 
individual: as men do not have great physical tools (no horns or strong teeth) to fight against each other), intellect stiffens metaphors ${ }^{5}$, in order to give them the ability to dominate the world. In this way, it provides the basis for ontology, science and logic. By stiffening a few metaphors, the intellect fixes a 'subject' in front of 'objects' and connects them to each other through causal links. The intellect does this by turning pale two types of metaphors: the first type of metaphors is the nervous impulse that produces the image, and the second type is the sound expression of the image.

[Der Sprachbildner] bezeichnet nur die Relationen der Dinge zu den Menschen und nimmt zu deren Ausdrucke die kühnsten Metaphern zu Hülfe. Ein Nervenreiz zuerst übertragen in ein Bild! erste Metapher. Das Bild wieder nachgeformt in einen Laut! Zweite Metapher. [...]Wir glauben etwas von den Dingen selbst zu wissen, wenn wir von Bäumen, Farben, Schnee und Blumen reden und besitzen doch nichts als Metaphern der Dinge, die den ursprünglichen Wesenheiten ganz und gar nicht entsprechen. (TL 1)

We can see the original metaphors as a higher level of creativity, aiming to the maximum of life (i.e. aiming to the power), and the pale metaphors as a lower level of creativity, aiming to the minimum of life (i.e., aiming to mere survival).

Language plays an important role in the sciences. While language is used, according to Brouwer, to maintain two wills oriented in a single direction, for Nietzsche the language (as a metaphor faded) creates and maintains a 'reality', useful in daily life but fictitious. In fact, according to Nietzsche, everything flows, or, better, what we perceive is only some flowing. Causality is appearance. Our belief in causality is faith in the strength that we experience when we do something. But nowhere the force moves things; the force we feel is not 'setting in motion the muscles'. Causality is created only by thought, which introduces the constraint in the process of succession.

The scientist considers true the content of his discipline. On the contrary, Nietzsche criticizes the alleged truth of science: it is, in fact, based on a world of fictitious entities interrelated in a fictional way on for the sake of certain survival purposes, while truth would be the absolute, the nonprospective, the non-anthropocentric:

Das „Ding an sich“ (das würde eben die reine folgenlose Wahrheit sein) ist auch dem Sprachbildner ganz unfasslich und ganz und gar nicht erstrebenswerth. (TL 1)

Die bestgeglaubten a priorischen „Wahrheiten“ sind für mich — Annahmen bis auf Weiteres z.B. das Gesetz der Causalität sehr gut eingeübte Gewöhnungen des Glaubens, so einverleibt, daß nicht daran glauben das Geschlecht zu Grunde richten würde. Aber sind es deswegen Wahrheiten? Welcher Schluß! Als ob die Wahrheit damit bewiesen würde, damit die Menschen bestehn bleibt! (NF$1884,26[12])$

For him, the content of science is an epistemological lie regulated by society; such knowledge is finalized, perspective, as well as mathematics and logic are. In its claim to truth, science is a faith, and, as such, it can be likened to religion. Nonetheless, Nietzsche realized and appreciated the fact that science was a danger to the priests, that want to keep the world of human needs and fears under their control:

Hat man eigentlich die berühmte Geschichte verstanden, die am Anfang der Bibel steht, — von der Höllenangst Gottes vor der Wissenschaft?... Man hat sie nicht verstanden. Dies Priester-Buch par excellence beginnt, wie billig, mit der grossen inneren Schwierigkeit des Priesters: er hat nur Eine grosse Gefahr, folglich hat „Gott“ nur Eine grosse Gefahr. (A 48) Der Anfang der Bibel

\footnotetext{
${ }^{5}$ Hinman (1982) stresses well that for Nietzsche language is essentially metaphoric because literally meaning would mean a complete coincidence between word and referent "for he clearly thinks that we begin to enter the domain of the metaphorical when we 'leave out' elements of the original experience as well as when we carry over meaning from another experience" (p. 183). I.e. Nietzsche aims to be fully consistent with the notion of a self-evident literality. Consequently, the metaphorical process begins for him with the act of perception itself, where: 1) we 'carry over' from one sphere (the physiological sphere of the nervous stimulus) to another (the domain of imagination); 2) we consider identical things those that have only some similarities in common. Secondly, the metaphorical process takes place in the transition from the image to the sound and finally in the transition from sound to word, where "metaphorical" is also the use of experiences as if they were equal when they are only similar.
} 
enthält die ganze Psychologie des Priesters. - Der Priester kennt nur eine grosse Gefahr: das ist die Wissenschaft — der gesunde Begriff von Ursache und Wirkung. [...]Wenn die natürlichen Folgen einer That nicht mehr „,natürlich“ sind, sondern durch BegriffsGespenster des Aberglaubens, durch „Gott“, durch „Geister“, durch „Seelen“ bewirkt gedacht werden, als bloss „moralische“ Consequenzen, als Lohn, Strafe, Wink, Erziehungsmittel, so ist die Voraussetzung zur Erkenntniss zerstört, — so hat man das grösste Verbrechen an der Menschheit begangen. - Die Sünde, nochmals gesagt, diese Selbstschändungs-Form des Menschen par excellence, ist erfunden, um Wissenschaft, um Cultur, um jede Erhöhung und Vornehmheit des Menschen unmöglich zu machen; der Priester herrscht durch die Erfindung der Sünde ${ }^{6}$. (A 49)

\section{Mathematics}

3.1. It is from his negative stance towards life, embedded in a mystical framework that referred especially to eastern tradition ${ }^{7}$ that Brouwer set his vision of mathematics and, consequently, of logic.

At the very beginning, in his Life, art and mysticism, he considered mathematics and logic as 'sharply indistinguable' and sinful. Namely he wrote about 'sinful bonds of science, of belief in "reality" and of logical thinking'. Furthermore, as van Dalen refers in his Mystic, Geometer and Intuitionist: The Life of L.E.J. Brouwer, there are undated notes which possibly belong to that period, where he wrote dispared opinions about mathematics:

One could see as the goal of one's life: Abolition and delivery from all mathematics. [...] That mathematics and its application are sinful follows from the intuition of time, which is immediately felt as sinful. [...] Mathematics justifies itself, needs no deeper ground than moral mysticism (van Dalen 1999b, 83-84)

Van Dalen interprets them as a reportage of a (successful) temptation: Brouwer's mystical view suggested him to avoid both a career and making studies/actions directed towards dominating nature, but his desires and abilities pulled him towards academical research in mathematics (van Dalen 1999b, p. 83). The solution that he found out to solve his paradoxical situation was to depict a new view of developing mathematics that could reduce at most mathematical sinfulness, inside a general framework of quiet acceptance of his own "karma". In 1906-1907 he described his dissertation as a duty $^{8}$, he separated mathematics from logic ${ }^{9}$, and began to carry out a research project of constructing mathematics 'in an inner way ${ }^{\prime 10}$. In his 1907 dissertation, by looking for something inner from which mathematics could start, he considered the Kantian aprioris - space and time -, pointed out the two meanings of 'apriority' (i.e. existence independent of experience and necessary condition for the possibility of science), let aside the first meaning (according to which all mathematics would be

\footnotetext{
${ }^{6}$ It is worthwhile to see nearer Brouwer's and Nietzsche's opinion about "sin". According to Brouwer, sin is what makes men unhappy during his life, because happiness can be found only in the Self (therefore, sin is trying to go out of the inner self): Brouwer got that idea from his mystical framework and kept it, because he was convinced that man could experience the fact that sin produces pain now. On the contrary, Nietzsche got a moralistic definition of sin from the Christian context where he lived: sin is the transgression of any of the prescriptions given by priests (that boat to have received them from God); sin is pleasure, is enjoying life, that is forbidden by priests by promising a future pain for it, after death. Therefore, Nietzsche refused the idea of sin as a repression of our vital instincts.

${ }^{7}$ See his quotes from the Bhagavad Gita in his "Life, art and mysticism" (LAM, p. 421, 423-424) and also in 1948 (CW I, p. 486).

${ }^{8}$ See letter to Scheltema 7.9.06 (keeping his Hinduistic references to the Bhagavad-Gita as a framework, he may have accepted as his fate, probably due to the clear attitude he had towards this discipline.)

${ }^{9}$ We see this in detail in the following paragraph. Here it is enough to recall a quote: "While thus mathematics is independent of logic, logic does depend upon mathematics". (CW I, p. 73)

${ }^{10}$ In the address delivered on the conferment upon G. Mannoury of the honorary degree of Doctor of Sciences, in 1946 , Brouwer credited Mannoury for having opened him the eyes over a mathematics full of life and, therefore, beautiful: "After two or three years of university, I still could see the figure of the mathematician only as a servant of natural sciences or as a collector of truths: - truth fascinating by their immovability, but horrifying by their lifelessness, like stones from barren mountains of disconsolate infinity [...] There I saw a man...I was captivated....mathematics had acquired a new character... These are harmonies I desired to realize". (CW I p. 474-475)
} 
apriori - non-Euclidean geometries as well as Euclidean geometry) and stated that, even if we would accept that we have no experience except in an empirical space where Euclidean geometry holds, we could admit that human intellect could place the concept of an external world in other receptacles without this being realized in practice. 'Human intellect disengages itself very well from threedimensional Euclidean geometry'. (CW I, p. 69) On the contrary, 'proper to man is a faculty which accompanies all his interactions with nature, namely the faculty of taking a mathematical view of his life, of observing in the world repetitions of sequences of events, i.e. of causal systems in time. The basic phenomenon therein is the simple intuition of time' (CW I, p. 53). Therefore, time is an a priori element in the sense that a scientific (causal) study of our experiences requires the intuition of time, provided that time is meant as intuitive time and not measured time, while neither time-intuition depends from an external experience nor an external experience requires time.

Did Brouwer still believe that time is 'immediately felt' as sinful? Presumably, he did. Namely, in 1908 he wrote:

In religious truth, i.e. wisdom, which abolishes the discernment between the subject and something different, and where the perception of time is no longer admitted, there is no mathematical understanding, let alone reliability of logic (CW I, p. 108)

Nevertheless, and notwithstanding with the fact that time aprioricity was obtained by (so to say) 'extracting' it out of the sinful science (and letting it to develop without applicational aims), Brouwer accepted time intuition because (at least) it was granted - through its independence of experience - as something inner.

In 1929 and in 1948 he refined his presentation of man's steps towards the science. In particular, in 1948 he introduced ${ }^{11}$ the distinction between consciousness and mind. The intuition of time takes place in consciousness, before it becomes mind, i.e. before the sinful separation of a 'subject' from an 'object': in this way mathematics has a source that is collocated at least in a 'less sinful' place. Then mathematics could be (sinfully) applied to the world by mind, but it can also be preserved pure by practicing it only on its own sake, for enjoying the pleasure of its beauty:

The fullest constructional beauty is the introspective beauty of mathematics, where the basic intuition of mathematics is left to free unfolding. This unfolding is not bound to the exterior world, and thereby to finiteness and responsibility; consequently its introspective harmonies can attain any degree of richness and clearness. (CW I, p. 484)

Hence, we can suppose that this distinction represented a further step towards the description of a not-sinful mathematics. It seems to me that his 1948 further remark supports this interpretation:

Searching for wisdom, we may find it in knowing that causal thinking or acting is non-beautiful and hard to justify, and that in the long run it brings disappointment. And in knowing that the exterior world with its innumerable individuals and with its hypertrophied cooperation is wedded to mind, its disharmonies reflecting mind's free-will-guilt ${ }^{12}$ (CW I, p. 485)

Here all what is negative is attributed to mind and to causal thinking/acting. So, we can suppose that the source for time is in 'a sin-free area'.

Now, how does mathematics develop out of the intuition of time before being applied to the natural world?

\footnotetext{
${ }^{11}$ The introduction of this distinction specifies better what he had written in 1907 in a footnote:

Strictly speaking the construction of intuitive mathematics in itself is an action and not a science; it only becomes a science, i.e. a totality of causal sequences, repeatable in time, i.e. a mathematics of the second order, which consists of the mathematical consideration of mathematics or of the language of mathematics. (CW I, p. 61).

${ }^{12}$ It is useful to stress that from this quote it comes out that "free will" is not always positively evaluated by Brouwer: only when it has its origin in the self it is positive!
} 
In his Ph.D. thesis Brouwer wrote: 'Mathematics develops out of its basic intuition in a self multiplication guided by an entirely free choice'. (CW I, p. 70)

Such development, in its appeal to 'free choice', resembled very much the description that he had given in 1905 of what happens if man seeks for interiority:

If you succeed in overcoming all inertia and proceed, you will find that passions will be silenced, you will feel dead to the old world of perception, of time and space, and all other forms of plurality [...] then you will understand the content of all your previous awareness and [...] you accept it as self -evident. [...] At the same time you are also aware of a wealth of phantasies, a mixture of all kinds of worlds [...] and in this confluent sea of colors, without separation, without firmness and yet about movement, this chaos without disorder, you see a direction, which you follow automatically, yet not of necessity. You will recognize your free will, free insofar that it can withdraw from the world of causality and remain free; it is only then that your will finds a definite direction, which it follows freely and reversibly. (LAM pp. 393-394)

More specifically, time is the source of natural numbers (and, with them, the source for the rational ones) with its scan instants- therefore, it is also called "intuition of the two-ity"; furthermore, he affirmed that time could give the intuition of the continuum, even if only as a whole and not of each of its points ${ }^{13}$. In 1914, he let see ${ }^{14}$ that he had a new opinion about this and in 1918 expressed the new opinion that the intuition of time also provides the framework for constructing ever-branching trees: if a mathematical entity already acquired (for example, a rational number) is associated to each node, the representation of the set of all real numbers, that is the continuum, is obtained. The branches of the continuum-tree were called by Brouwer 'free-choice sequences' because they could be completely free (lawless) $)^{15}$. The construction of the tree - in its generic shape - was described as follows:

Eine Menge ist ein Gesetz, auf Grund dessen, wenn immer ein willkürlicher Zifferncomplex der Folge 1,2,3... gewählt wird, jede dieser Wahlen entweder ein bestimmtes Zeichen oder nichts erzeugt oder aber die Hemmung des Prozesses und die definitive Vernichtung seines Resultates herbeiführt, wobei für jedes $n>1$ nach jeder ungehemmten Folge von $\mathrm{n}$ 1 Wahlen wenigstens ein Ziffernkomplex gewählt wird, nicht die Hemmung des Prozesses herbeiführt. (CW I, p.150)

It is initially called 'Menge' because it is the first type of set that Brouwer could point out of time intuition (later, it will be called by him 'spread'). The other type, presented in 1918 too, was that of a group ${ }^{16}$ of entities (already available), called 'Species':

Unter einer Species erster Ordnung verstehen wir eine Eigenschaft, welche nur eine mathematische Entitaet besitzen $\mathrm{kann}^{17}$; unter einer Spezies zweiter Ordnung verstehen wir eine Eigenschaft, welche nur eine mathematische Entitaet oder

\footnotetext{
13 This position was in line with the French tradition of intuitionism: in particular, with the following excerpt from the lecture given by Borel at the International Congress of Mathematics in Rome in 1908, where he took part: 'I consider this notion [of the continuum] as obtained from the geometric intuition : it is known that the concept of full arithmetic continuum requires that one admits the legitimacy of an infinite countable series of choices. This seems to me highly questionable legitimacy, but nevertheless one should distinguish between legality and legitimacy of this more than countable infinity of choices (simultaneous or successive)'. (Troelstra 1982, p. 467) This quote explains why it is possible to describe Brouwer's initial position in terms of acceptance of the geometric continuum but not the arithmetic one. In addition, it sheds light on the origin of the name (later also adopted by Brouwer) of 'free choice sequences' for the sequences in question.

${ }^{14}$ In his review of Schoenflies and Hahn's book Die Entwickelung der Mengenlehre und ihrer Anwendungen (CW I, p.140).

${ }^{15}$ About this subject (with all its historical and philosophical details that go beyond the domain of the present paper) see van Atten 2003, 2004, 2007; van Dalen 1999 a and b; Niekus 1987, 2005 and 2011; Troelstra 1982. Here we just have to specify something about the expression "creating subject" that appears in Brouwer's last writings in his counterexamples to logical principles meaning the mathematician that produces real numbers according to some given conditions. As for concerns our comparison Brouwer/Nietzsche it is essential to have clear that Brouwer intended to describe the activity of the mathematician, his living construction of free choice sequences (and the result of such activity). There is no trace in Brouwer's papers that could allow to hold that Brouwer intended to present the new figure of "mathematical subject".

${ }^{16}$ Brouwer gave always an intensional definition of set.

17 „Mengen und Elemente von Mengen werden Mathematische Entitaeten genannt“ (CW I p. 150)
} 
Species erster Ordnung besitzen kann. In analoger Weise definieren wir Species n-ter Ordnung, wo $n$ ein beliebiges Element von A repraesentiert ${ }^{18}$. (CW I $\left.150-151\right)$

Brouwer's description of 'Menge' remained unchanged ${ }^{19}$ till the years 1946-1951, when he got Griss' criticism to the possibility of considering as part of mathematics hypothetical constructions which cannot be finished ${ }^{20}$. From that period on, Brouwer preferred to avoid sterilization and described the tree as having:

1) As nodes of order 1 either all the natural numbers or only those not larger the a given $m$;

2) As nodes of order $n+1$ (for all $n$ 's) either the immediate descendants of the node $p$ of order $n$, or only those descendants whose $(n+1)$ th component added to $p$ 's components is not larger than a given number $m_{p}$.

In order to obtain the spread, to each node he attached either terms or nothing.

During the construction of the tree, there was choice freedom, because each row represented a free choice sequence. Brouwer thought such possibility of choice over and over. In 1929, in all his copies of his 1925 paper about sets, he added ${ }^{21}$ (about free choice sequences) 'Inklusive des Charakters ihrer Fortsetzbarkeitsfreiheit, welche sich nach jeder Wahl beliebig eventuell bis zur völligen Bestimmtheit, oder auch einem Mengengesetze entsprechend verengern kann.' (CW I, p. 590)

In 1946 he changed his mind and became definitively convinced that:

In former publications I have sometimes admitted restrictions of freedom with regard also to future restrictions of freedom. However this admission is not justified by close introspection and moreover would endanger the simplicity and rigor of further developments. (CW I, p. 511)

In his later writings, he described intuitionistic mathematics as consisting of two acts:

First act of intuitionism

Completely separating mathematics from mathematical language and hence from the phenomena of language described by theoretical logic, recognizing that intuitionistic mathematics is an essentially languageless activity of the mind having its origin in the perception of a move of time. This perception of a move of time may be described as the falling apart of a life moment into two distinct things, one of which gives way to the other, but is retained by memory. If the twoity thus born is divested of all quality, it passes into the empty form of the common substratum of all twoities. And it is this common substratum, this empty form, which is the basic intuition of mathematics.

Second act of intuitionism

Admitting two ways of creating new mathematical entities: firstly in the shape of more or less freely proceeding infinite sequences of mathematical entities previously acquired ; secondly, in the shape of mathematical species, i.e. properties supposable for mathematical entities previously acquired, satisfying the condition that, if they hold for a certain mathematical entity, they also hold for all mathematical entities which have been defined to be ' equal ' to it, definitions of equality having to satisfy the conditions of symmetry, reflexivity and transitivity. (CL 4-8)

From these two ' acts ', mathematics must be developed by the two-ity through successive mental steps that must go by evidence to evidence. This reference to evidence has its reason in the fact that 'truth is only in reality, i.e. in the present and past experience of consciousness' ${ }^{22}$. (CW I, p. 488) There are no fixed rules of evidence, but rather new ways of moving from insight to insight, experiencing a vivid sense of beauty:

18 "A is the set of natural numbers.

${ }^{19}$ (CW I, p. 301).

${ }^{20}$ On this subject see Franchella (1994c).

21 Troelstra (1982b, p. 473) recalls that something similar can be found in Brouwer's notes to his Berliner Lectures.

${ }^{22}$ We recall here that two special cases of a so defined truth were immanent truth ("truth which in this world points to the inevitability of the karma of that world") and transcendental truth ("truth which guides man in this world toward a personal life, free from the shackles of fear and deside" LAM, pp. 392-393). 
The fullest constructional beauty is the introspective beauty of mathematics, where instead of elements of playful causal thinking, the basic intuition of time is left to free unfolding. This unfolding is not bound to the exterior world, end thereby to finiteness and responsibility; consequently its introspective harmonies can attain any degree of richness and clearness (CW I p. 484)

Since mathematics does not follow fixed rules, logic must undergo a rearrangement rather strong. It becomes the collection of regularities in the expressions of mathematics.

3.1. There is not much place devoted specifically to mathematics among Nietzsche's considerations. For him, arithmetic was based on the concept of 'Ego' (which is configured as a unity) and on the existence of identical things. Thus, mathematics was based, like logic and science, on the series of lies or 'truth -looking statements', which are useful for survival. (We need to be able to count units: this does not mean that such units exist.)

Wir haben den Begriff der Einheit entlehnt von unserem „Ich“begriff, — unserem ältesten Glaubensartikel. (NF 1888, 14[79])

Die Zahl. - Die Erfindung der Gesetze der Zahlen ist auf Grund des ursprünglich schon herrschenden Irrthums gemacht, dass es mehrere gleiche Dinge gebe (aber thatsächlich giebt es nichts Gleiches), mindestens dass es Dinge gebe (aber es giebt kein „Ding“). Die Annahme der Vielheit setzt immer voraus, dass es Etwas gebe, das vielfach vorkommt: aber gerade hier schon waltet der Irrthum, schon da fingiren wir Wesen, Einheiten, die es nicht giebt. - Unsere Empfindungen von Raum und Zeit sind falsch, denn sie führen, consequent geprüft, auf logische Widersprüche. Bei allen wissenschaftlichen Feststellungen rechnen wir unvermeidlich immer mit einigen falschen Grössen: aber weil diese Grössen wenigstens constant sind, wie zum Beispiel unsere Zeit- und Raumempfindung, so bekommen die Resultate der Wissenschaft doch eine vollkommene Strenge und Sicherheit in ihrem Zusammenhange mit einander; man kann auf ihnen fortbauen — bis an jenes letzte Ende, wo die irrthümliche Grundannahme, jene constanten Fehler, in Widerspruch mit den Resultaten treten, zum Beispiel in der Atomenlehre. (HH I, 19)

Geometry is also based on a liar leveling of sensory experiences: we never perceive straight lines, circles, dots; we introduce them into reality to make it static, predictable and controllable so that it becomes reassuring.

Ebenso steht es mit der Mathematik, welche gewiss nicht entstanden wäre, wenn man von Anfang an gewusst hätte, dass es in der Natur keine exact gerade Linie, keinen wirklichen Kreis, kein absolutes Grössenmaass gebe. (HH I, 11)

We see that Nietzsche had not referred to Kant to explain the foundation of mathematics, as Brouwer later did when proposed time intuition as its source. Still, like Brouwer, Nietzsche referred to the question of the morality of mathematics (as part of the general question of the morality of human knowledge), but only to explain why there was no negative moral judgment by society about mathematics, the sciences and logic while there was for lies in general. The answer was that mathematics (as also sciences and logic) are useful lies and regulated by society: that's why they are so culturally acceptable to be transmitted as truths.

Notwithstanding with the scarce references to mathematics that can be traced in Nietzsche's works, E. Steinhart (1999, p. 25) set up a parallel between Nietzsche's thought and intuitionism. Firstly, he suggested a link between mathematics and moral in the fact that the 'strict honesty' that is required to practice mathematics teaches us a strict discipline in introspection, teaches us a critical attitude that allows us to keep us away from superstition.

Then, Steinhart stressed that Brouwer attributed to mathematics an artistic nature that Nietzsche would have appreciated. The artistic nature of mathematics would consist in the fact that mathematics is built according to Brouwer - hence it is an 'architectural', artistic activity - and free, 'conditioned by the sole bond of non- contradiction'. Indeed, Brouwer uses the metaphor of "building" throughout his life, from the beginning to the end of his work. In his dissertation, he wrote:

the only possible foundations of mathematics must be sought in this construction under the obligation carefully to watch which construction intuition allows and which not, and why any other attempt at such a foundation is condemned to failure (CWI, p. 52) 
and in his 1949 paper "Consciousness, Philosophy and Mathematics", he stated: "[...] intuitionistic mathematics is inner architecture" (CW I, p. 494) Indeed, for Brouwer mathematics was a (joyful and) free construction, but 'free' meant 'not finalized' and 'lawless'; 'free' did not mean 'noncontradictory': the condition of non-contradictoriness is absolutely far from Brouwer. Namely, he sees non-contradiction as a result of doing mathematics in a constructive way, not as a criterion of doing mathematics. Non- contradiction was a necessity for Hilbert's finitism, which conceived the various branches of mathematics as axiomatic systems expressed in a symbolic and formal way: coherence was necessary for such formal systems as a guarantee for their content. Namely, from a system that admits an internal contradiction any formula can be derived as a result, including a statement and its negation, and this makes the system completely useless. Brouwer always criticized this point of view, which he considered merely 'linguistic', not based on a mental content. In 1912 Brouwer wrote in 'Intuitionism and Formalism':

The intuitionist can never feel assured of the exactness of a mathematical theory by such guarantees as the proof of its being non- contradictory, the possibility of defining its concepts by a finite number of words, or the practical certainty that it will never lead to a misunderstanding in human relations (CW I, p. 128).

In 1928 he reiterated this opinion in the text 'Intuitionistische Betrachtungen über den Formalismus':

Die Erkenntnis dass die (inhaltliche) Rechtfertigung der formalistischen Mathematik durch den Beweis ihrer Widerspruchslosigkeit einen circulus vitiosus enthält, weil diese Rechtfertigung auf der (inhaltichen) Richtigkeit der Aussage, dass aus der Widerspruchslosigkeit eines Satzes die Richtigkeit dieses Satzes folge, d.h. auf der (inhaltlichen) Richtigkeit des Satzen vom ausgeschlossenen Dritten beruht (CW I, p. 410)

Therefore at no moment of his life Brouwer accepted non-contradiction as a 'guarantee' for mathematics. He preserved his original opinion that he had expressed in Life, Art and Mysticism:

A language that does not derive its certainty from the human will but which claims to live on in a pure concept is an absurdity. It is indeed a great skill to be able to go on speaking without being caught in contradiction or without making silent presumptions rooted in the will [...] but a kind of skill one admires in an acrobat (LAM, p. 403)

Hence, we can share with Steinhart the idea that Nietzsche would have appreciated Brouwer's artistic vision of mathematics, insofar as Nietzsche encouraged every form of creativity, but we cannot accept that Brouwer put on mathematics the condition of being non-contradictory.

Finally, Steinhart proposes an analogy in the birth of mathematics according to the two authors. For both, it would arise from the division of time: according to Nietzsche it would arise from the division of the temporal continuum into equal parts, and according to Brouwer from the scheme of the duounit in the flow of perceptions. It should be noted, however, that Nietzsche did not insist on the aspect of temporality (which is, on the contrary, important to Brouwer, and it is explicitly stressed by him), but on identity and, particularly, on the specific identity of the 'Ego' as a foundation for unity.

\section{Logic}

4.1. For Brouwer logic does not express the human creative ability but is a sedimentation of second level. The proof of theorems is an inner, creative experience, because, by performing them, the man tries new roads and sees where they lead. He does not follow rules, and such activity resembles what Brouwer had written about the self in 1905: 'you see a direction, which you follow automatically, yet not of necessity. You will recognize your free will' (LAM p. 394). 
Mathematics, that is all interior, does not require language, which is used to communicate and, therefore, it does not require to go sinfully out of the self ${ }^{23}$. Language occurs later, to communicate its results. What is logic? If we look at the linguistic expression of the mathematical experience and collect the regularities that we find, then we obtain logic. If we would change the linguistic expression, logic would change too ${ }^{24}$. Logic does not certify psychological data, but ethnological ones.

People try by means of sounds and symbols to originate in other people copies of mathematical constructions and reasonings which they have made themselves; by the same means they try to aid their own memory. In this way the mathematical language comes into being and is a special case the language of logical reasoning. [...] given the same organization of the human intellect and consequently the same mathematics, a different language would have been formed, into which the language of logical reasoning, well known to us, would not fit. [...] We infer that theoretical logic as well as logistic are empirical sciences and that they apply mathematics; consequently they can yield no information whatsoever on the organization of human intellect; there would be better reasons to reckon them under ethnography than under psychology. (CW I, 73-74).

Initially, logical laws appeared trivial to Brouwer. They either expressed an identity (law of identity, non-contradiction and the excluded middle ${ }^{25}$ ) or an inclusion (the law of syllogism). Brouwer did not criticise either the principle of identity nor, more fundamentally, the concept of identity, because he accepted everything that could be found out in the interior, in the Self. He rejected the distinction between subject and object, because it turned man away from the Self but he did not deny the law of identity, because identification could take place within the Self.

Furthermore, he believed that 'the mathematics of whole and part' (i.e. syllogistic) was useless in the empirical world:

The mathematics of whole and part [=syllogistic] does not teach us through its theory anything new for application. Once the system is applied to a part of the observational world, even a very mediocre intellect can immediately read off all the consequences: no intermediary logical reasoning is necessary. (Letter from Brouwer to Korteweg 23.01.1907 p. 39)

And that:

One knows well that the world is not a logical system and one cannot argue logically about it (ibidem)

It serves only lawyers and demagogues, not to instruct other people but to deceive them, and that is because the vulgar herd unconsciously reasons: the language with its logical figures is there, so it will be useful and so they meekly let themselves be deceived; just as I heard several people defend their habit of gin drinking with the words: 'What else is gin for?' Whoever has the illusion to improve the world, may just as well agitate against the language of logical reasoning as against alcohol. (ibidem)

However, in 1908, immediately after the discussion of the Ph.D. thesis, Brouwer criticized the principle of the excluded middle, because, if logic has to be an expression of mathematics, it would

\footnotetext{
${ }^{23}$ Brouwer in a second time realized that human memory can fail and made a quick mention of this. In 1933, in fact, at the conference "Willen, weten, spreken" ("Volition, knowledge and talk") spoke of "an ideal mathematician without limitation of memory, which could do without the language" (CW I, p. 443): it is a sign that Brouwer realized that speaking of a mathematical construction made without the support of the language is unreal. Language should be given a role in mathematics, to support the weak human memory. However, he did not develop further this hint and never regained the argument, that was focused by his student Arend Heyting. For Brouwer mathematics remained an alinguistic activity.

${ }^{24}$ On the relationships between logic and language in Brouwer see also van Dalen 1999c.

${ }^{25}$ In his dissertation, Brouwer presented also the principle of excluded middle as a statement of identity. Namely, he wrote: "'A function is either differentiable or not differentiable' says nothing; it expresses the same as the following: 'If a function is not differentiable, then it is not differentiable'." (CW I, p. 75) In the following year he will change his mind, as we are going to see.
} 
have to speak of mathematical reality. So, affirming $\mathrm{P}$ meant giving the mental construction of $\mathrm{P}$, and negating $\mathrm{P}$ meant showing the failure of the construction of $\mathrm{P}$ :

The words of your mathematical demonstration merely accompany a mathematical construction that is effected without words. At the point where you enounce the contradiction, I simply perceive that the construction no longer goes, that the required structure cannot be imbedded in the given basic structure. (CW I, p. 73)

Therefore, the principle of the excluded middle meant that, for any property and for any entity, we could always either provide a demonstration that the entity has the property or lead to failure any attempt to demonstrate that. In other words, the principle of the excluded middle became the assertion of the possession of the solution of all mathematical questions that might ever be asked (CW I, p. 109). This was much more than what Aristotle meant to say with the same principle, and therefore it could not be accepted as a logical law. Namely, it is enough a single mathematical problem still unsolved in order to suspend the validity of the law. At the end, as a side effect of his vision of life, Brouwer had originated a logic alternative to the classical one.

4.2. Nietzsche referred to Aristotelian logic and believed that it allows us to posit things as equal, even if we only perceives continuous changing.

Die Logik ist geknüpft an die Bedingung: gesetzt, es giebt identische Fälle. Thatsächlich, damit logisch gedacht und geschlossen werde, muß diese Bedingung erst als erfüllt fingirt werden. Das heißt: der Wille zur logischen Wahrheit kann erst sich vollziehen, nachdem eine grundsätzliche Fälschung alles Geschehens vorgenommen ist. Woraus sich ergiebt, daß hier ein Trieb waltet, der beider Mittel fähig ist, zuerst der Fälschung und dann der Durchführung Eines Gesichtspunktes: die Logik stammt nicht aus dem Willen zur Wahrheit. (NF 1885, 40[13])

Logic does not emerge from the objective data in our possession but is a pattern that we sneak onto the continuous flow of perceptions in order to make it controllable and, hence, non-anxiogenic: 'die Logik beruhigt, giebt Vertrauen' (370 GS)

Logic, like science and mathematics, is a useful simplification to avoid drowning in uncertainty or anxiety, but it is not 'true' in the profound sense of the term. This simplification is not intrinsic to man but is the product of the evolution of the human species and has been preserved due to its survival function: men who had started to see less clearly the differences, began to see a uniformity in perceptions, began to distinguish objects, to classify them (leaves, food), and so became able to get food and defend themselves. In this way they survived longer than the others, could reproduce themselves and pass this trait to their offspring.

Herkunft des Logischen. - Woher ist die Logik im menschlichen Kopfe entstanden? Gewiss aus der Unlogik, deren Reich ursprünglich ungeheuer gewesen sein muss. Aber unzählig viele Wesen, welche anders schlossen, als wir jetzt schliessen, giengen zu Grunde: es könnte immer noch wahrer gewesen sein! Wer zum Beispiel das „Gleiche“ nicht oft genug aufzufinden wusste, in Betreff der Nahrung oder in Betreff der ihm feindlichen Thiere, wer also zu langsam subsumirte, zu vorsichtig in der Subsumption war, hatte nur geringere Wahrscheinlichkeit des Fortlebens als Der, welcher bei allem Aehnlichen sofort auf Gleichheit rieth. Der überwiegende Hang aber, das Aehnliche als gleich zu behandeln, ein unlogischer Hang — denn es giebt an sich nichts Gleiches - , hat erst alle Grundlage der Logik geschaffen. Ebenso musste, damit der Begriff der Substanz entstehe, der unentbehrlich für die Logik ist, ob ihm gleich im strengsten Sinne nichts Wirkliches entspricht, - lange Zeit das Wechselnde an den Dingen nicht gesehen, nicht empfunden worden sein; die nicht genau sehenden Wesen hatten einen Vorsprung vor denen, welche Alles „,im Flusse“ sahen. An und für sich ist schon jeder hohe Grad von Vorsicht im Schliessen, jeder skeptische Hang eine grosse Gefahr für das Leben. Es würden keine lebenden Wesen erhalten sein, wenn nicht der entgegengesetzte Hang, lieber zu bejahen als das Urtheil auszusetzen, lieber zu irren und zu dichten als abzuwarten, lieber zuzustimmen als zu verneinen, lieber zu urtheilen als gerecht zu sein — ausserordentlich stark angezüchtet worden wäre. - Der Verlauf logischer Gedanken und Schlüsse in unserem jetzigen Gehirne entspricht einem Processe und Kampfe von Trieben, die an sich einzeln alle sehr unlogisch und ungerecht sind; wir erfahren gewöhnlich nur das Resultat des Kampfes: so schnell und so versteckt spielt sich jetzt dieser uralte Mechanismus in uns ab. (GS, 111) 
Now such attitude is consolidated so as not to appear as a tool dropped on perception but as intrinsic to an external 'reality' and to a static 'subject',

Was den Aberglauben der Logiker betrifft: so will ich nicht müde werden, eine kleine kurze Thatsache immer wieder zu unterstreichen, welche von diesen Abergläubischen ungern zugestanden wird, - nämlich, dass ein Gedanke kommt, wenn „er“ will, und nicht wenn ,ich“ will; so dass es eine Fälschung des Thatbestandes ist, zu sagen: das Subjekt ,ich“ ist die Bedingung des Prädikats „denke“. Es denkt: aber dass dies „es“ gerade jenes alte berühmte „Ich“ sei, ist, milde geredet, nur eine Annahme, eine Behauptung, vor Allem keine „unmittelbare Gewissheit“. Zuletzt ist schon mit diesem „es denkt“ zu viel gethan: schon dies „es“ enthält eine Auslegung des Vorgangs und gehört nicht zum Vorgange selbst. Man schliesst hier nach der grammatischen Gewohnheit „Denken ist eine Thätigkeit, zu jeder Thätigkeit gehört Einer, der thätig ist, folglich - “. (BGE 17)

According to Nietzsche, the classification operated by logic has also moral consequences (the formation of the moral of the herd):

Der Calcul „thue nichts, was dir selber nicht angethan werden soll“ verbietet Handlungen um ihrer schädlichen Folgen willen: der Hintergedanke ist, daß eine Handlung immer vergolten wird. [...] Dagegen ist der Spruch werthvoll, weil er einen Typus Mensch verräth: es ist der Instinkt der Heerde, der sich mit ihm formulirt - man ist gleich, man nimmt sich gleich: wie ich dir, so du mir Hier wird wirklich an eine Äquivalenz der Handlungen geglaubt, die, in allen realen Verhältnissen, einfach nicht vorkommt. Es kann nicht jede Handlung zurückgegeben werden: zwischen wirklichen „Individuen“ giebt es keine gleiche Handlung, folglich auch keine „Vergeltung“... Wenn ich etwas thue, so liegt mir der Gedanke vollkommen fern, daß überhaupt dergleichen irgend einem Menschen möglich sei: es gehört mir... Man kann mir Nichts zurückzahlen, man würde immer eine „andere“ Handlung gegen mich begehen (NF $1888,22[1])$

This may appear a clear attitude of hostility from Nietzsche against logic. Still, he also emphasized the importance of learning at school how to think:

Die Schule hat keine wichtigere Aufgabe, als strenges Denken, vorsichtiges Urtheilen, consequentes Schliessen zu lehren: desshalb hat sie von allen Dingen abzusehen, die nicht für diese Operationen tauglich sind, zum Beispiel von der Religion. (HH 1, 265);

expressed some appreciation to the Jews for their subtlety and perfection in deduction (that they due to the necessity of adducing reasons to convince their opponents during the centuries ):

Ein Jude umgekehrt ist, gemäss dem Geschäftskreis und der Vergangenheit seines Volks, gerade daran — dass man ihm glaubt — am wenigsten gewöhnt: man sehe sich darauf die jüdischen Gelehrten an, — sie Alle halten grosse Stücke auf die Logik, das heisst auf das Erzwingen der Zustimmung durch Gründe; sie wissen, dass sie mit ihr siegen müssen, selbst wo Rassen- und Classen-Widerwille gegen sie vorhanden ist, wo man ihnen ungern glaubt. (GS 348)

and criticised the causa sui as a logical violation:

Die causa sui ist der beste Selbst-Widerspruch, der bisher ausgedacht worden ist, eine Art logischer Nothzucht und Unnatur: aber der ausschweifende Stolz des Menschen hat es dahin gebracht, sich tief und schrecklich gerade mit diesem Unsinn zu verstricken. (BGE 21)

Which was really Nietzsche's evaluation of logic 26 ?

\footnotetext{
${ }^{26}$ Maudemarie Clark (1991, p. 105) assumed a change of opinion about logic by Nietzsche on the basis of the following expression: "Oder Formal-Wissenschaft, Zeichenlehre: wie die Logik und jene angewandte Logik, die Mathematik. In ihnen kommt die Wirklichkeit gar nicht vor, nicht einmal als Problem; ebensowenig als die Frage, welchen Werth überhaupt eine solche Zeichen-Convention, wie die Logik ist, hat.” (TI III 3). The change of opinion would consist of not seeing reference to reality in logic any longer.

Stephen Hales replied to this interpretation firstly by suggesting to recognize that the author style would consist in general of making a breaking statement, denying it and then taking it partially; secondly by explaining the supposed "change" of Nietzsche's opinion about logic through the distinction between syntax and semantics. When Nietzsche referred to logic as a ' doctrine of signs ', he had in mind what we today call the syntax. Therefore, it makes sense that he said that such (aspect of) logic did not 'touch' the ontological - metaphysical issues. When, however, Nietzsche discussed the connections between logic and ontology referred to that aspect of logic that we now call semantics. In other words, Nietzsche refers to two different aspects of logic when he says, respectively, that logic does not touch ontological questions and when he says that it touches them.
} 


\section{Opinions about Nietzsche in comparison}

There is not much material about Nietzsche's logic in the literature: there seems to be a general opinion that Nietzsche criticized logic. I recall here Stephen Hales' and Ophelia Schutte's viewpoints because they devoted a more attentive eye to the subject and gave meaningful contributions.

Hales firstly stressed two facts:

1) Nietzsche did not know anything about the logical stars of XIX century - Boole and Frege, in particular (Hales 1996, p. 820);

2) when Nietzsche discussed the connections between logic and ontology, he referred to that aspect that we now call semantics (Hales 1996, p. 823).

Secondly, Hales focused on the fact that the central core of Nietzsche's criticism consisted of the fact that logic assumes identity of objects, and then he pointed out the aspects implied or assumed by such criticism, namely: 1) logic presupposes the existence of objects; 2) things are just fictions invented by humans; 3) logic presupposes an identity of objects that endure over time, 4) logic assumes the identity of objects to a certain instant, 5) there is identity through time; 6) nothing is self- identical, or self-identical objects are only fictions. (Hales 1996, p. 824)

Finally Hales affirmed that semantics presupposes the existence of objects, but not necessarily in a realistic way. Semantics refers to a domain but this can consist of fictitious objects. Thus, according to Hales, Nietzsche's position on logic is not destructive: we can agree with Nietzsche about the fictitious character of the objects of logic without necessarily putting logic aside, because when semantics refers to objects, it does so without realistic pre- conditions. (Hales 1996, p. 835)

On her side, Ophelia Schutte (1984, p. 28-36) gave her interpretation of Nietzsche's philosophy of logic by referring to the contrast between the Apollonian and Dionysian, expressed by the author in The Birth of Tragedy. He had noticed that in classical Greece two types of gods had emerged: Dionysus, god of vitality, whose unbridled instinct might strike terror, and Apollo, god of the order, of the rational calm. At first there were the Dionysian cults that had come from the East. The Greeks knew them, had fear of unbridled joy and pain, and began their worship of Apollo, designed precisely to stem the invasion of the Dionysian. The interaction between the two types of deities gave rise to the tragedy, which produced a balance between Dionysian instinct and the Apollonian calm. The balance was shattered by Socrates that has unbalanced the scales in favor of rationality. An application to logic could come out of this perspective. Namely, Schutte pointed out an opposition between logic and the Dionysian view of life: logic makes things static, while Dionysus expressed the dynamism of life through dance and music. Schutte proposed a way to recover logic within a Nietzschean perspective, by being aware that logic aims to specific purposes (the survival). This recovery can be done in Dionysian terms: the process must be mediated by a Dionysian acceptance of life so that man can be free both from the bondage of the exclusive authority of reason and from a dualistic view of life (that would be formed by the contrast between life and non-life).

Having in mind Hales' and Schutte's contributions, we can now try to make us an opinion on the matter. First, we somehow share Hales' suggestion to consider not adequate Nietzsche's criticism to logic as presupposing the existence both of objects and of a subject. It must be pointed out that 
Nietzsche believed that logic shares the subject-object structure of ordinary language, while, from Frege onwards, the way in which logic expresses the sentences of ordinary language is in terms of function - argument, borrowed from mathematics and certainly neutral from an ontological point of view. However, Nietzsche did not know Frege's work. We recall here that in the nineteenth century the traditional formal logic got a substantial modification due to the contribution of some mathematicians in Britain and in Germany ${ }^{27}$. Namely, in Germany a transformation of logic was operated by the mathematician Ernst Schröder, by establishing an abstract view of mathematics which focused not on mathematical objects, but on symbolic operations with arbitrary objects. The result was an algebra of logic, that developed parallel to (and independent of) its British counterpart, whose main author was George Boole. In such a framework Frege's contribution took place. He was a mathematician, too, and aimed to a rigorous foundations of arithmetics. In this perspective, he shaped a new symbolic language that could allow to go further the monopolistic deductive structure of syllogism and offer an adequate axiomatization of arithmetics on a pure logical basis. Still, his "ideography" (Begriffsschrift) had a bad fortune even among the mathematicians. So, it is well comprehensible that the philosopher Nietzsche did not know it. Much less could he know the contributions to semantics stemming from Alfred Tarski, who wrote thirty years after his death. Now we can say that logic has no more claim to describe reality and that it simply proposes its tools to those who have the need to treat the identity and the diversity. Now we can say that logic does not necessarily preserve the subject-predicate structure of everyday language. The reference of logic that Nietzsche had was Aristotle's one, who actually meant to describe reality in terms of subject / predicate. So, as far as Nietzsche knew of logic, that is, as far as we remain in the frame of Aristotelian logic, his two criticisms were centered.

Furthermore, he was certainly revolutionary for the following reasons. 1) He did not present logic as something absolute but as something perspective (i.e., aiming at some specific purpose - in particular, the material survival). 2) He considered logic as a result of natural selection, emerging due to its success in bringing food and, therefore, in offering people more possibilities for reproducing themselves.

As regards, then, his 'evaluation' of logic, Schutte's suggestion can be accepted and we can even say that it was directly proposed by Nietzsche himself. It is my opinion that in Nietzsche we can find traces of his considering an important thing for man taking into account both irrationality and rationality. Nietzsche recognized that the Dionysian is the authentic form of life, but he was also aware of the risks that can arise if man indulges totally in it. Therefore, we can see in this quotation a kind of opening to the Apollonian under the form of a calibrated use of logic as a tool for survival providing that it does not take away space for the expansion of creativity. That was the situation in Greece at the time of the tragedy, before the advent of Socrates, a time of balancing between the Apollonian and the Dionysian that Nietzsche appreciated. Namely, he described with negative words Euripides' changes in tragedy, that echoed the prevalence of the Apollonian attitude after the golden period of the Sophoclean tragedy, according to a "Socratic esthetics" and that destroyed art at all:

\footnotetext{
${ }^{27}$ About the interplay between philosophy and mathematics in shaping logic in the nineteenth century see Peckhaus 1999. At the time, in Germany the philosophical discussions around logic concerned Hegel's variant of logic, according to which logic coincided with metaphysics. After Hegel's death, "the logical question" (formulated by Trendelenburg) was "Is Hegel's dialectical method of pure reasoning a scientific procedure?" (see Peckhaus 1999, p. 438.) In Britain, the first half of the $19^{\text {th }}$ century saw the development of inductive logic (Mill, Bain) and some work around the problem of trying to express the quantification of predicate inside the syllogisms, after that Whately's book "Elements of logic" (1826) had recalled the attention on formal logic. The birth of the algebra of logic, that represented the first step towards the astonishing renewal of formal logic, took place both in German and in Britain quite independently of the philosophical debate around logic (even if Boole refers to it - see Peckhaus 1999, p. 436)
} 
verharren wir hier einen Augenblick, um uns jenen früher geschilderten Eindruck des Zwiespältigen und Incommensurabeln im Wesen der aeschyleischen Tragödie selbst in's Gedächtniss zurückzurufen. Denken wir an unsere eigene Befremdung dem Chore und dem tragischen Helden jener Tragödie gegenüber, die wir beide mit unseren Gewohnheiten ebensowenig wie mit der Ueberlieferung zu reimen wussten - bis wir jene Doppelheit selbst als Ursprung und Wesen der griechischen Tragödie wiederfanden, als den Ausdruck zweier in einander gewobenen Kunsttriebe, des Apollinischen und des Dionysischen. [...] Jenes ursprüngliche und allmächtige dionysische Element aus der Tragödie auszuscheiden und sie rein und neu auf undionysischer Kunst, Sitte und Weltbetrachtung aufzubauen — dies ist die jetzt in heller Beleuchtung sich uns enthüllende Tendenz des Euripides.[...] Dionysus war bereits von der tragischen Bühne verscheucht und zwar durch eine aus Euripides redende dämonische Macht. [...] so werden wir jetzt dem Wesen des aesthetischen Sokratismus schon näher treten dürfen; dessen oberstes Gesetz ungefähr so lautet: „alles muss verständig sein, um schön zu sein“; als Parallelsatz zu dem sokratischen „,nur der Wissende ist tugendhaft.“ Mit diesem Kanon in der Hand maass Euripides alles Einzelne und rectificirte es gemäss diesem Princip: die Sprache, die Charaktere, den dramaturgischen Aufbau, die Chormusik.(GT 12) Hier überwächst der philosophische Gedanke die Kunst und zwingt sie zu einem engen Sich-Anklammern an den Stamm der Dialektik. In dem logischen Schematismus hat sich die apollinische Tendenz verpuppt (GT 14).

Socrates, the "inspirer" of such changes, represents the "logical man" that Nietzsche blames, because he repressed vitality, by developing (and teaching to develop) only one of our brains:

Angesichts dieses praktischen Pessimismus ist Sokrates das Urbild des theoretischen Optimisten, der in dem bezeichneten Glauben an die Ergründlichkeit der Natur der Dinge dem Wissen und der Erkenntniss die Kraft einer Universalmedizin beilegt und im Irrthum das Uebel an sich begreift. In jene Gründe einzudringen und die wahre Erkenntniss vom Schein und vom Irrthum zu sondern, dünkte dem sokratischen Menschen der edelste, selbst der einzige wahrhaft menschliche Beruf zu sein: so wie jener Mechanismus der Begriffe, Urtheile und Schlüsse von Sokrates ab als höchste Bethätigung und bewunderungswürdigste Gabe der Natur über alle anderen Fähigkeiten geschätzt wurde. (GT 16)

But, like the science, practiced till its extreme point, discovers its limits: "Nun aber eilt die Wissenschaft, von ihrem kräftigen Wahne angespornt, unaufhaltsam bis zu ihren Grenzen, an denen ihr im Wesen der Logik verborgener Optimismus scheitert." (GT 15), analogously, Socrates, the logical man, feels his second brain, his Dionysian instinct knocking at the door:

Jener despotische Logiker hatte nämlich hier und da der Kunst gegenüber das Gefühl einer Lücke, einer Leere, eines halben Vorwurfs, einer vielleicht versäumten Pflicht. Oefters kam ihm, wie er im Gefängniss seinen Freunden erzählt, ein und dieselbe Traumerscheinung, die immer dasselbe sagte: „Sokrates, treibe Musik!““ [...]Jenes Wort der sokratischen Traumerscheinung ist das einzige Zeichen einer Bedenklichkeit über die Grenzen der logischen Natur: vielleicht — so musste er sich fragen - ist das mir Nichtverständliche doch nicht auch sofort das Unverständige? Vielleicht giebt es ein Reich der Weisheit, aus dem der Logiker verbannt ist? Vielleicht ist die Kunst sogar ein nothwendiges Correlativum und Supplement der Wissenschaft? (GT 14)

Nietzsche outlined strengths and limitations of both sides of the man, and called for a collaboration:

Desshalb muss eine höhere Cultur dem Menschen ein Doppelgehirn, gleichsam zwei Hirnkammern geben, einmal um Wissenschaft, sodann um Nicht-Wissenschaft zu empfinden: neben einander liegend, ohne Verwirrung, trennbar, abschliessbar; es ist diess eine Forderung der Gesundheit. Im einen Bereiche liegt die Kraftquelle, im anderen der Regulator: mit Illusionen, Einseitigkeiten, Leidenschaften muss geheizt werden, mit Hülfe der erkennenden Wissenschaft muss den bösartigen und gefährlichen Folgen einer Ueberheizung vorgebeugt werden. (HH I, 251)

Therefore, would say that Nietzsche's criticism to logic did not intend to discard logic but consisted only in de-mythologizing it mainly in two ways, by stressing that:

1) it works but it is not true: it does not describe reality - because there is no reality; 2) there is something else, besides logic: human creativity, which cannot be overshadowed, or relegated as less important than it.

This explains his apparent 'change of mind' or oscillation about logic: he simply considered positive and negative consequences of the logical viewpoint.

\section{A final comparison}


We have seen that in Brouwer and Nietzsche there is a path that leads directly from the vision of life to their opinion about science, mathematics and logic ${ }^{28}$.

Nietzsche and Brouwer partly agree about science. For both it consists of projecting the pattern of causality onto the world. Brouwer sees it as a sinful exercise of the will of man over nature, that triggers a series of researches chained through causal links. It may even happen that man forgets the initial goal and produces an opposite effect to that which had originally sought. Nietzsche does not consider anything as sinful, but in any case he judged science negatively, because it goes against life in its creativity, its effervescence. Science is part of the tools that man has invented in order to feel reassured in the universe of perceptions and changing. Such tools consist of framing and categorizing , in order to keep everything under control. And this goes precisely in the opposite direction to what favors the booming of the vital, the individual, the unique, the special.

As for mathematics, Brouwer distinguishes it from science and, therefore, he 'saves' it only on condition that he redefines the boundaries of a constructivist mathematics, that is not targeted to be applicative. It must be carried out as an expansion of the intuition of time: therefore, mathematics is creative and free from preconceived methods. Therefore, it is also free from logic. This is not applied when doing mathematics, but, on the contrary, it comes after mathematics as an extrapolation of the regularities that can be found only in retrospect in the expression of mathematics. Mathematics, in itself, is something a-linguistic (because language, according to Brouwer, is used only to communicate). Nietzsche shares of Brouwer the meaning and appreciation of creativity but he includes mathematics in the same field of science and logic; he considers it as something schematic and repetitive, based on the forced distinction between subject and object: for him, the ego is the source reference, the prototype for the production of units for the calculation.

Nietzsche and Brouwer reject the view of a unique logic intrinsic to man. For both, logic is a human product. For Brouwer logic is not a list of correct reasoning-patterns applied when proving new theorems: logic comes after mathematics, as a kind of statistics on its accompanying language. Therefore, it is conditioned by culture and, consequently, by ethnicity like any other discipline that refers to the language. Furthermore, its set of laws cannot remain the same because logic must express a mental content, i.e. an evidence of mind. Even negation must express some evidence: the evidence of the fact that the construction of a proof fails. Therefore, the principle of the excluded third is to affirm the holding of the resolution of all mathematical problems and, thus, it becomes and remains unreliable as long as an open mathematical problem still exists. In fact, nonetheless his lack of interest in logic, Brouwer had obtained a new one as a 'side effect' of a program for a new foundation of mathematics. The details of such intuitionistic logic will be developed by his student Arend Heyting. In any case, for what concerns Brouwer, the Aristotelian logic was not intrinsic to

\footnotetext{
${ }^{28}$ We can reconsider here Tasić's short comparison between Brouwer and Nietzsche. We have seen that Brouwer and Nietzsche do agree about the concept of "will", but - we should add - only partially. "Will" is for both of them "will to power", but Nietzsche considered it very positively, as the source of energy in life, while Brouwer considered it negatively, as the source of dissatisfaction and, hence, of pain in life. For both of them the "reality" offered by the science is only appearance, but Nietzsche believed that there was no reality at all, while Brouwer believed in a transcendent, undefinable reality to which man realizes to belong only after his death (a reality to which he alluded through references to Boehme: "When all images are removed from the soul, and she beholds the Only One, then the naked essence of the soul finds the naked formless essence of the Divine Unity, the presence of the superior being waiting in the self" LAM p. 393.) Surely, only Brouwer sees creativity in mathematics, while Nietzsche sees creativity in the arts. What would Nietzsche have react to Brouwer's view of mathematics? Obviously, we cannot be sure of his reaction, but we can imagine that Nietzsche would found some difficulties in appreciating a mathematics that was so linked to the "intuition of time" (that is a capacity of individuating instants) of the subject. This link would have also prevented Nietzsche from considering intuitionistic mathematics as "true": such mathematics was clearly perspective (due to a specific capability!), therefore it could not be absolute, as required from Nietzsche to consider something as true.
} 
man, it was not something that man has in his own frame of mind: it could be replaced by another logic.

For Nietzsche - which referred to an Aristotelian framework- logic serves to identify, to draw boundaries, to stabilize, while we experience a continuous flow of perceptions. Logic is a product of human evolution, finalized at our survival: it is not something absolute, but it is aim-oriented. If for Brouwer there may be truth in logic only in the moment in which it describes a mathematical reality; for Nietzsche there can never be truth in logic. Still, Brouwer had a profound contempt for logic, while it was not only negativity that Nietzsche attributed to logic: he appreciated the use of logic to argue and persuade, and complained the poor exercise of the deduction in German schools and universities. He just wanted to determine exactly the limits of logic, to stress that it has not an absolute value. The two sides of the human, the rational and the irrational (the two brains, as Nietzsche called them) - coexist and should be made inter-act without penalizing anyone. The rational side smooths, allowing survival. The irrational side innovates, creates, leaves out the strong emotions, the uniqueness, the individuality of each person.

With an eye to the twenty-first century, we point out that logic is a tool: it offers its laws to administer the identity, but it does not place the identity. Logic could even exist as a mere intellectual exercise. Furthermore, identity can also be fictitious. It is not necessary that it is 'true' (i.e. nonperspective). However, this is a view typical of the twenty-first century: it took another hundred years after Nietzsche until this awareness could be reached. Such awareness was obtained ignoring Nietzsche's contribution, perhaps because in the nineteenth century logic had moved from a philosophical frame towards a mathematical frame. On the contrary, Brouwer has directly contributed to such awareness, by providing a new logic that was different from the traditional one. Other non-classical logics were later introduced (modal, fuzzy, quantum logic for example), welcoming the (Nietzschean) opinion that logic is a human product, driven by certain needs and aiming at very specific purposes in well-defined areas, and gave to the broader idea of the existence of a pluralistic range of logics.

\section{Bibliography}

Nietzsche's quotations in this article come from Friedrich Nietzsche, Digital critical edition of the complete works and letters, based on the critical text by G. Colli and M. Montinari, Berlin/New York, de Gruyter 1967-, edited by Paolo D'Iorio. Where it is not expressly stated that it mentions the page, the reference refers to the aphorism number.

Abbreviations:

$A=$ Der Antichrist (The Antichrist)

$B G E=$ Jenseits von Gut und Böse (Beyond Good and Evil)

$G M=$ Zur Genealogie der Moral (On the Genealogy of Morals)

GS= Die fröhliche Wissenschaft (The Gay Science)

$H H=$ Menschliches, Allzumenschliches (Human, All Too Human)

NF=Nachgelassene Fragmente (Posthumous Fragments)

$T I=$ Götzen-Dämmerung (Twilight of the Idols) 
$T L=$ Über Wahrheit und Lüge im aussermoralischen Sinne (On Truth and Lies in an Extra-moral Sense)

\section{Z=Also sprach Zarathustra (Thus Spoke Zarathustra)}

Brouwer's Abbreviations

$\mathrm{CL}=$ Cambridge Lectures

LAM= Life, Art and Mysticism

Van Atten, M. 2003. Brouwer, as Never Read by Husserl, Synthese 137, 3-19.

Van Atten, M. 2004. On Brouwer, Belmont (CA): Wadsworth.

Van Atten, M. 2007. Brouwer Meets Husserl. On the Phenomenology Of Choice Sequences, Berlin: Springer.

Brouwer, L.E.J. 1905. Leven, kunst en mystiek, Delft: Waltman; engl.transl. "Life, Art and Mysticism“, Notre Dame Journal of Formal Logic 37, 389-430.

Brouwer, L.E.J. 1975. Collected Works vol. 1 (A. Heyting ed.), North-Holland, Amsterdam.

Brouwer, L.E.J. 1981. Brouwer's Cambridge Lectures in Intuitionism (D. van Dalen ed.), Cambridge, Cambridge U.P. Brouwer, L.E.J. (1991) Intuitionismus (D. van Dalen ed.), Mannheim: B.-I. Wissenschaftsverlag.

Brouwer L.E.J. - Adama van Scheltema C.S. (1984) Droeve snaar, vriend van mij. Brieven. (D. van Dalen ed.), Amsterdam: De Arbeiderspers.

Clark, M. 1991. Nietzsche on Truth and Philosophy. Cambridge: Cambridge UP.

Van Dalen, D. 1999a. From Brouwerian Counterexamples to the Creating Subject, Studia Logica 62, 305-314.

van Dalen, D. 1999b. Mystic, geometer and intuitionist: the life of L. E. J. Brouwer. Vol I : The dawning revolution. Oxford: Clarendon.

Van Dalen, D. 1999c. The Role of Language and Logic In Brouwer's Work. In Orlowska E. (ed.) Logic in Action, Vienna: Springer, 3-14.

van Dalen, D. 2005. Mystic, geometer and intuitionist: the life of L. E. J. Brouwer. Vol II : Hope and disillusion, Oxford, Clarendon.

Van Dalen, D. 2011. The Selected Correspondence of L.E.J. Brouwer. Berlin: Springer.

van Dalen, D. 2013. L. E. J. Brouwer. Topologist, intuitionist, philosopher. How mathematics is rooted in life, Berlin: Springer.

Franchella, M. 1994. L.E.J. Brouwer pensatore eterodosso, Milano: Guerini.

Franchella, M. 1994b. Heyting's Contribution to the Change in Research into the Foundations of Mathematics, History and Philosophy of Logic 15, 149-172.

Franchella, M. 1994c. "Brouwer and Griss on Intuitionistic Negation", 1994, Modern Logic 4/3, 256-265

Franchella, M. 1995a. L.E.J. Brouwer Towards Intuitionistic Logic , Historia Mathematica 22, 304-322.

Franchella, M. 1995b. Like a Bee on a Windowpane: Heyting's Reflections on Solipsism, Synthese 105, 207-251

Franchella, M. 2001. Come l'amor platonico: Kantismo e platonismo nella filosofia della matematica del XX secolo, Milano: Led.

Franchella, M. 2008. Con gli occhi negli occhi di Brouwer: filosofie della matematica a confronto con l'intuizionismo. Polimetrica: Monza.

Hales, S.D. 1996. Nietzsche On Logic. Philosophy and Phenomenological Research 56(4): 819-835.

Hinman, L. M. 1982. Nietzsche, Metaphor, and Truth. Philosophy and Phenomenological Research 43(2): 179-99.

Koetsier, T. 2005. Arthur Schopenhauer and L.E.J. Brouwer: a comparison, in T. Koetsier - L. Bergmans (eds.) Mathematics and the Divine. A Historical Study. Elsevier, Amsterdam, 569-594.

Niekus, J. M. 1987 The Method of the Creative Subject, Proceedings Koninklijke Akademie van Wetenschappen. Series A 4, 431-443.

Niekus, J.M. 2005 Individual Choice Sequence in the Work of L.E.J. Brouwer, Philosophia Scientiae 217-232.

Niekus, J.M. 2011 Brouwer's Incomplete Objects. History and Philosophy of Logic 31(1): 31-46.

Pasley, M. 1978 (ed.) Nietzsche: Imagery and Thought, London: Metheuen.

Peckhaus, V. 1999. 19th Century Logic between Philosophy and Mathematics. The Bulletin of Symbolic Logic 5: 433450

Schrift, A. D. 1985. Language, Metaphor, Rhetoric: Nietzsche's Deconstruction of Epistemology. Journal of the History of Philosophy 23(3): 371-95.

Schutte, O. 1984. Beyond Nihilism: Nietzsche without Masks. Chicago: University of Chicago Press.

Sonderegger, S. 1973. Friedrich Nietzsche und die Sprache: Eine sprachwissenschaftlich Skizze. Nietzsche Studien (2) $1-30$.

Steinhart, E. 1999. Nietzsche's Philosophy Of Mathematics, International Studies in Philosophy 31(3): 19-27. 
Stack, G. J. 1981. Nietzsche and the Correspondence Theory of Truth. Dialogos 16 (November 1981): 93-118. van Stigt, W.P. 1990. Brouwer's Intuitionism, North-Holland, Amsterdam.

Tarski, A. 1933. "The concept of truth in the languages of the deductive sciences" (Polish), Prace Towarzystwa Naukowego Warszawskiego, Wydzial III Nauk Matematyczno-Fizycznych 34, Warsaw; expanded English translation in Tarski 1983, 152-278.

Tarski, A. 1944. "The semantic conception of truth", Philosophy and Phenomenological Research, 4 (3): $341-376$.

Tarski, A. 1983. Logic, Semantics, Metamathematics, papers from 1923 to 1938, Indianapolis: Hackett Publishing Company.

Tasić, V. 2001. Mathematics and the Roots of Postmodern Thought, Oxford: Oxford U.P.

Troelstra, A. S 1982. On the Origin and Development of Brouwer's Concept of Choice Sequences, in Troelstra A.S. van Dalen D. (eds.) The L.E.J. Brouwer Centenary Symposium, Amsterdam: North-Holland, 465-488.

Thurnher, R. 1980. Sprache und Welt bei Friedrich Nietzsche. Nietzsche Studien 9 (1980): 38-60.

Ungeheuer, G. 1983. Nietzsche über Sprache und Sprechen, über Wahrheit und Traum. Nietzsche Studien (1983)134-213.

Walters, K. S. 1982. The Ontological Basis of Nietzsche's Perspectivism. Dialogue 24 (April 1982): 35-46.

Warnock, M. 1978. Nietzsche's Conception of Truth. In Pasley 1978, 33-63.

Whately, R. 1828 Elements of logic. London: Mawman. 